\title{
Management of lymphangioleiomyomatosis
}

\section{Angelo M. Taveira-DaSilva* and Joel Moss}

\author{
Address: Cardiovascular and Pulmonary Branch, NHLBI, NIH Building 10, Room 6D03, MSC 1590, Bethesda, Maryland 20892-1590, USA \\ *Corresponding author: Angelo M. Taveira-DaSilva (dasilvaa@nhlbi.nih.gov) \\ FI000Prime Reports 2014, 6:116 (doi:10.12703/P6-I16) \\ All Fl000Prime Reports articles are distributed under the terms of the Creative Commons Attribution-Non Commercial License \\ (http://creativecommons.org/licenses/by-nc/3.0/legalcode), which permits non-commercial use, distribution, and reproduction in any medium, \\ provided the original work is properly cited. \\ The electronic version of this article is the complete one and can be found at: http://f $1000 . c o m /$ prime/reports $/ \mathrm{m} / 6 / \mathrm{I} / 6$
}

\begin{abstract}
Lymphangioleiomyomatosis (LAM), a multisystem disease affecting almost exclusively women, is characterized by cystic lung destruction and presents with dyspnea, recurrent pneumothoraxes, chylous effusions, lymphangioleiomyomas, and angiomyolipomas. It is caused by the proliferation of a cancer-like LAM cell that possesses a mutation in either the tuberous sclerosis complex (TSC) I or TSC2 genes. This article reviews current therapies and new potential treatments that are currently undergoing investigation. The major development in the treatment of LAM is the discovery of two mammalian target of rapamycin (mTOR) inhibitors, sirolimus and everolimus, as effective drugs. However, inhibition of mTOR increases autophagy, which may lead to enhanced LAM cell survival. Use of autophagy inhibitors, for example, hydroxychloroquine, in combination with sirolimus is now the subject of an ongoing drug trial (SAIL trial). Another consequence of mTOR inhibition by sirolimus is an increase in Rho activity, resulting in reduced programmed cell death. From these data, the concept evolved that a combination of sirolimus with disruption of Rho activity with statins (e.g. simvastatin) may increase TSC-null cell death and reduce LAM cell survival. A combined trial of sirolimus with simvastatin is under investigation (SOS trial). Since LAM occurs primarily in women and TSC-null cell survival and tumor growth is promoted by estrogens, the inhibition of aromatase to block estrogen synthesis is currently undergoing study (TRAIL trial). Other targets, for example, estrogen receptors, mitogen-activated protein kinase inhibitors, vascular endothelial growth factor-D signaling pathway, and Src kinase, are also being studied in experimental model systems. As in the case of cancer, combination therapy may become the treatment of choice for LAM.
\end{abstract}

\section{Introduction}

In this review we discuss the treatment of LAM, a multisystem orphan disease affecting almost exclusively women, which is associated with cystic lung destruction and extra-pulmonary abnormalities consisting of abdominal tumors (e.g. angiomyolipomas), lymphatic tumors (e.g. lymphangioleiomyomas), and chylous effusions (Table 1 and Figure 1) [1-4]. The pathological features of LAM result from proliferation of a neoplastic LAM cell that has characteristics both of smooth muscle cells and melanocytes [3]. Lung lesions consist of infiltrates of LAM cells in the walls of cysts and along blood vessels, lymphatics and bronchioles, leading to airway obstruction, vascular wall thickening, lymphatic damage, and venous occlusion [2,3]. LAM lesions comprise two types of cells: spindle-shaped and epithelioid $[2,3]$. Both cell types react with antibodies against smooth muscle antigens, for example, $\alpha$-actin, vimentin and desmin. The epithelioid cells react with human melanin black antibody (HMB-45), a monoclonal antibody that recognizes a premelanosomal protein (gp100) that is encoded by the Pmel17 gene [2,3]. In the proper clinical setting, positive reaction to HMB-45 is virtually diagnostic of LAM [2-4].

LAM presents with dyspnea, recurrent pneumothoraxes, pleural effusions, ascites, and bleeding angiomyolipomas $[4,5]$. In most women, dyspnea and recurrent pneumothoraxes dominate the clinical picture, being a major cause of morbidity. In some cases, lung disease 
Table I. Frequent manifestations of lymphangioleiomyomatosis

\begin{tabular}{ll}
\hline Pulmonary disease & Extrapulmonary disease \\
\hline Thin-walled lung cysts & Angiomyolipomas \\
Chylous pleural effusions & Chylous ascites \\
Pneumothorax & Lymphadenopathy \\
& Lymphangioleiomyomas \\
& Meningiomas \\
& Decreased bone mineral density \\
\hline
\end{tabular}

Figure I. Computed tomography scan images of pulmonary and extrapulmonary features of lymphangioleiomyomatosis
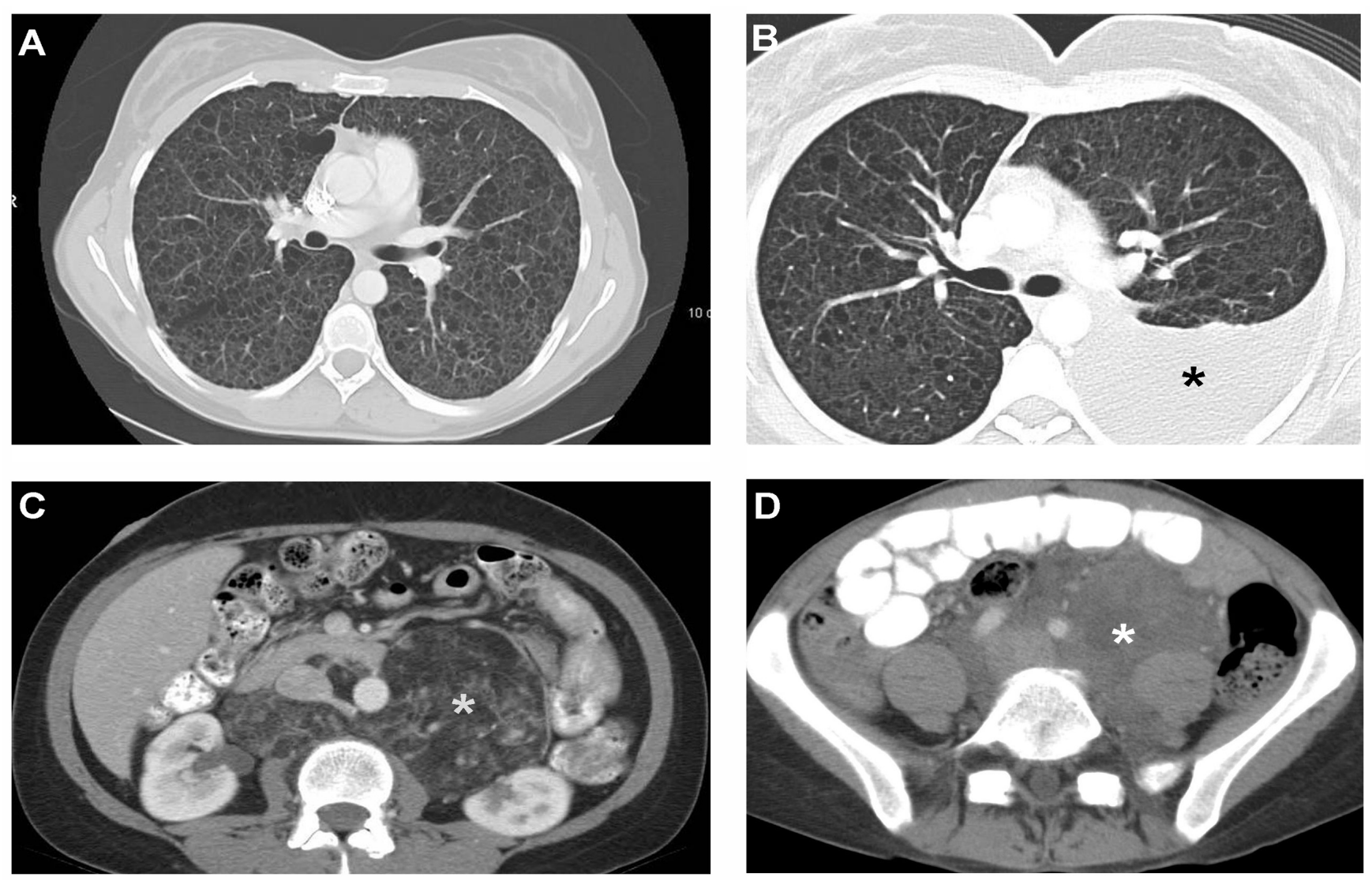

Panel A: Computed tomography (CT) scan of the thorax showing numerous thin-walled cysts scattered throughout the lungs, which have almost completely replaced the normal lung parenchyma. Panel B: CT scan of the thorax showing a left chylothorax (black star). Panel C: CT scan of the abdomen shows a large angiomyolipoma in a patient with tuberous sclerosis complex and lymphangioleiomyomatosis (LAM). The fatty, low density component is clearly visualized and is indicated by the white star. Panel D: CT scan of the abdomen shows a large, fluid-filled lymphangioleiomyoma (white star) surrounding vascular structures.

Abbreviations: CT, Computed tomography; LAM, lymphangioleiomyomatosis.

progresses slowly, with decline in lung function leading to respiratory failure $[5,6]$. In others, usually younger women, LAM tends to run a more rapid course. Lung function abnormalities consist of decreased expiratory flow expressed as a reduction in forced expiratory volume in the first second $\left(\mathrm{FEV}_{1}\right)$, and decreased lung diffusion capacity $\left(\mathrm{DL}_{\mathrm{CO}}\right)$, leading to a reduction in breathing capacity and hypoxemia during exercise or at rest $[1,5-7]$.

Two forms of LAM have been described. The inherited form of LAM is reported to occur in up to $81 \%$ of women with tuberous sclerosis complex (TSC) [8], an autosomal dominant disorder characterized by hamartomatous 
tumors involving the central nervous system, skin, liver, heart and eyes, and associated with mental retardation, seizures and autism [9]. The sporadic form of LAM has been reported to occur in 3.3-7.7 million women [10]. In either form, LAM is caused by mutations in the tuberous sclerosis complex 1 (TSC1) or tuberous sclerosis complex 2 (TSC2) genes [11-13] that encode two proteins, hamartin and tuberin.

LAM is considered to be a low-grade malignancy. Data are consistent with a metastatic model. Identical TSC2 mutations have been found in the lungs and kidneys of the same patient with sporadic LAM $[11,12]$. Loss of heterozygosity of TSC2 has been demonstrated in LAM cells isolated from lung, angiomyolipomas, blood, chyle, and urine from patients with sporadic LAM and TSC-LAM [11-15].

LAM cells have been detected in donor lungs of patients who had lung transplantation $[16,17]$. These findings support the possibility that migration to the lungs of cells from other sites, such as the kidney, lymphatic system, or uterus may occur [16-18].

Hamartin and tuberin together inhibit the mammalian target of rapamycin (mTOR) signaling pathway, a major regulator of cell size and proliferation [19]. mTOR inhibitors, sirolimus and everolimus, have been proven effective in stabilizing lung function and reducing the size of chylous effusions, lymphangioleiomyomas and angiomyolipomas [20-22].

The severity of lung disease and its rate of progression is best assessed by clinical symptoms, histological grading of lung biopsy tissue, pulmonary function tests, computed tomography imaging, six-minute walk tests and cardiopulmonary exercise tests [5]. The clinical data are used to determine the need to treat patients with mTOR inhibitors.

In this article, we will focus on targeted therapies shown to be effective in LAM, and other agents that appear to be promising and are currently undergoing either preclinical or clinical testing. We will discuss how these potential treatments are expected to complement the actions of mTOR inhibitors. Finally, we will discuss the treatment of pneumothoraxes, chylous effusions, and angiomyolipomas as well as issues related to pregnancy and lung transplantation.

\section{General principles of management}

Patients should be told that LAM is a chronic disease with a median transplant-free survival time of approximately 29 years from the onset of symptoms and a 10-year transplant-free survival of $86 \%$ and that, as much as possible, they should lead a normal life $[5,23,24]$. Patients should be encouraged to lose excess weight, engage in physical activities, and exercise regularly. Levels of exercise should be limited only by the severity of lung disease. Sports involving physical contact and martial arts should be avoided because of the potential for bleeding in patients who have angiomyolipomas. Patients should be allowed to travel by land or air, except to high-altitude locations, depending on disease severity and risk of pneumothorax. The risk of a life-threatening pneumothorax associated with air travel is minor [25]. However, sudden onset of breathlessness or chest pain suggesting the presence of a pneumothorax should be investigated and ruled out prior to air travel. Arterial blood gases assist in determining whether a patient may travel by air without supplemental oxygen. A six-minute walk test or a cardiopulmonary exercise test to uncover exercise-induced hypoxemia and determine the need for supplemental oxygen is recommended [5,7]. Because of the potential risks of estrogens in the pathogenesis of LAM, a disease found primarily in women, patients should be advised against using estrogen-containing contraceptives and foods.

\section{Targeted therapies \\ Mammalian target of rapamycin (mTOR) inhibitors}

TSC1 and TSC2 encode, respectively, hamartin and tuberin $[19,26-28]$, two proteins that regulate the intracellular serine/threonine kinase mTOR signaling pathway, a major regulator of cell size, proliferation and survival $[19,26]$ (see Figure 2). mTOR is the catalytic subunit of two distinct complexes named mTOR complex 1 (mTORC1) and mTOR complex 2 (mTORC2) [19]. The hamartin/tuberin complex regulates mTORC1 negatively through its actions on Rheb (Ras homolog enriched in brain). Tuberin is a GTPase-activating protein for the guanine nucleotide-binding protein Rheb that converts active Rheb-GTP into the inactive Rheb-GDP form [19]. In the absence of functional tuberin, caused by TSC2 gene mutations, there is accumulation of active Rheb-GTP and stimulation of mTORC1. Activation of mTORC1 leads to phosphorylation of S6 kinase and eukaryotic initiation factor 4E-binding protein as well as increased protein translation, and cell size and proliferation $[19,29]$. mTORC2 is a mediator of actin cytoskeletal organization, cell cycle progression and cell survival $[19,27]$. mTORC2 controls Rho and protein kinase B (Akt), and through its effects on Akt, promotes cell survival $[19,27]$.

Sirolimus and everolimus are two immunosuppressant compounds that form a complex with FK506-binding protein-12, and inhibit mTORC1 [19]. mTOR inhibitors have been shown to decrease tumor size in the Eker rat 
Figure 2. Simplified diagram of the mammalian target of rapamycin (mTOR) signaling pathway and its relationship with autophagy and apoptosis

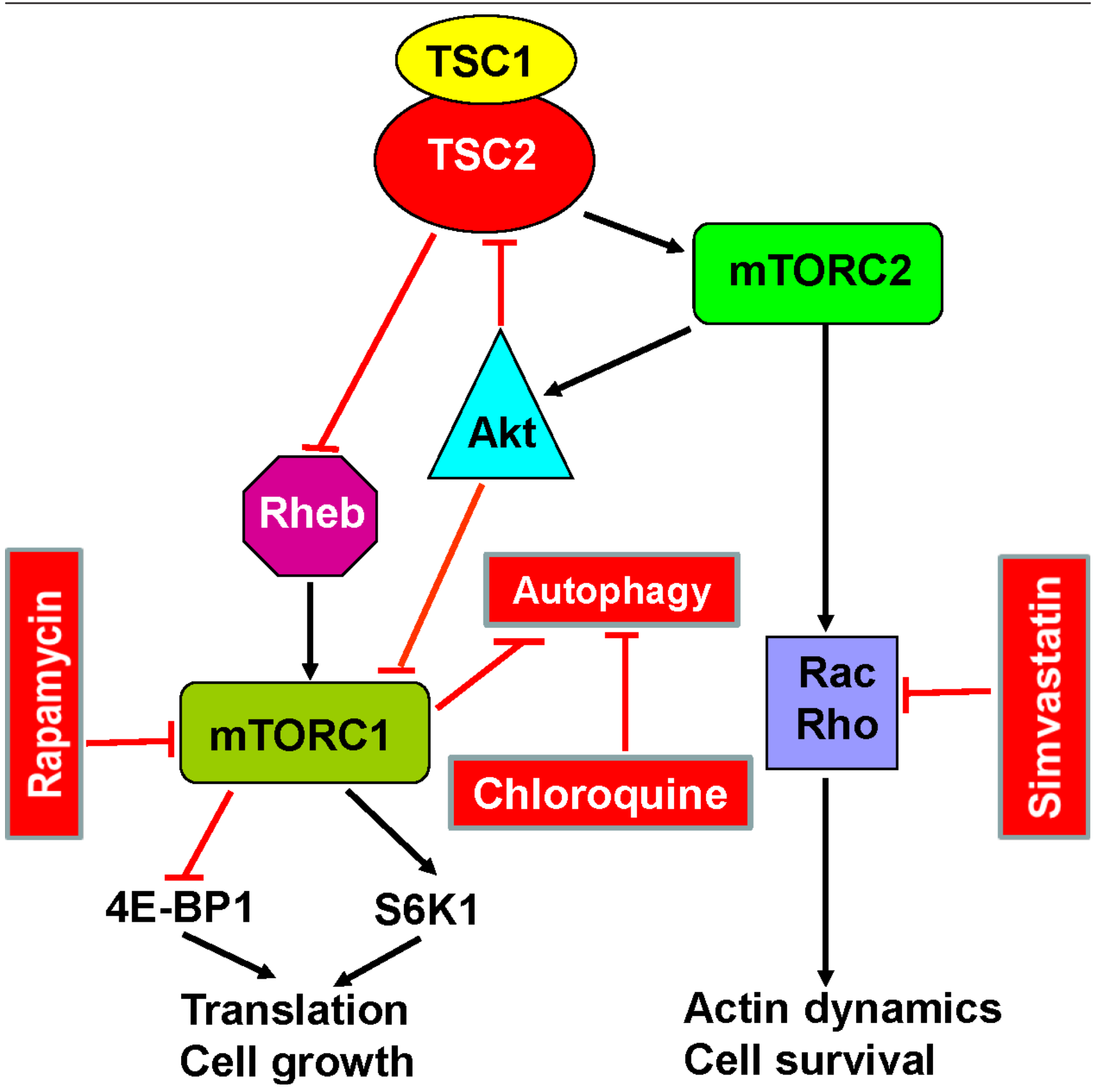

Tuberous sclerosis complex (TSC) I/2 integrates multiple signals to control cell size and proliferation. TSCI/2 regulates mammalian target of rapamycin (mTOR) complex I mTORCI negatively through its actions on Rheb. Activation of mTORCI leads to protein translation, cell growth and proliferation. mTORCI is a major regulator of autophagy. Blockade of mTORCI by sirolimus augments autophagy, leading to increased cell survival. This effect can be inhibited by hydroxychloroquine. mTOR complex 2 (mTORC2) regulates the actin cytoskeleton through Rho GTPases, which affect cell migration,

morphogenesis and apoptosis. Simvastatin reduces Rheb and Rho activities and promotes apoptosis. Combined therapy with sirolimus, hydroxychloroquine or simvastatin may act synergically to inhibit lymphangioleiomyomatosis (LAM) cell growth and promote apoptosis.

Abbreviations: Akt, protein kinase B; mTOR, mammalian target of rapamycin; mTORCI, mTOR complex I; mTORC2, mTOR complex 2; Rac, small GTPase binding protein of the Rho family; Rheb, Ras homolog enriched in brain; S6KI, S6 kinase I; 4E-BPI, factor 4E binding protein I; TSC, tuberous sclerosis complex. 
model of TSC [30], decrease the growth of renal cystadenomas and liver hemangiomas in Tsc2 ${ }^{+-}$mice, and decrease tumor growth and mortality in a mouse model with $T s c 2^{+/-}$tumors [31]. Several clinical studies have demonstrated the efficacy of mTORC1 inhibitors in the treatment of LAM [20-22]. A double-blinded, placebo-controlled study (MILES trial) testing the effect of sirolimus on pulmonary function was undertaken in 89 women with LAM. Forty-six patients were treated with sirolimus and 43 with placebo for 12 months [20]. Patients were followed for a year after discontinuation of therapy [20]. Compared to the placebo group, the sirolimus group had improvements from baseline in vital capacity, $\mathrm{FEV}_{1}$, quality of life, and functional performance. After discontinuation of sirolimus, lung function decline resumed and was no different from that of the placebo group [20]. In another study [21], sirolimus was proven effective in reducing the size of chylous effusions, ascites, and abdominal lymphangioleiomyomas in 12 patients with lymphatic involvement who were treated for approximately 2.5 years (Figure 3 ). Nine of the 12 patients experienced complete resolution of their chylous effusions and abdominal lymphangioleiomyomas [21] (see Figure 3).

Based on current evidence, it is recommended that sirolimus or everolimus be used to treat LAM patients in whom lung function is declining rapidly or those who

Figure 3. Effect of sirolimus in lymphangioleiomyomatosis patients with chylous effusions and lymphangioleiomyomas
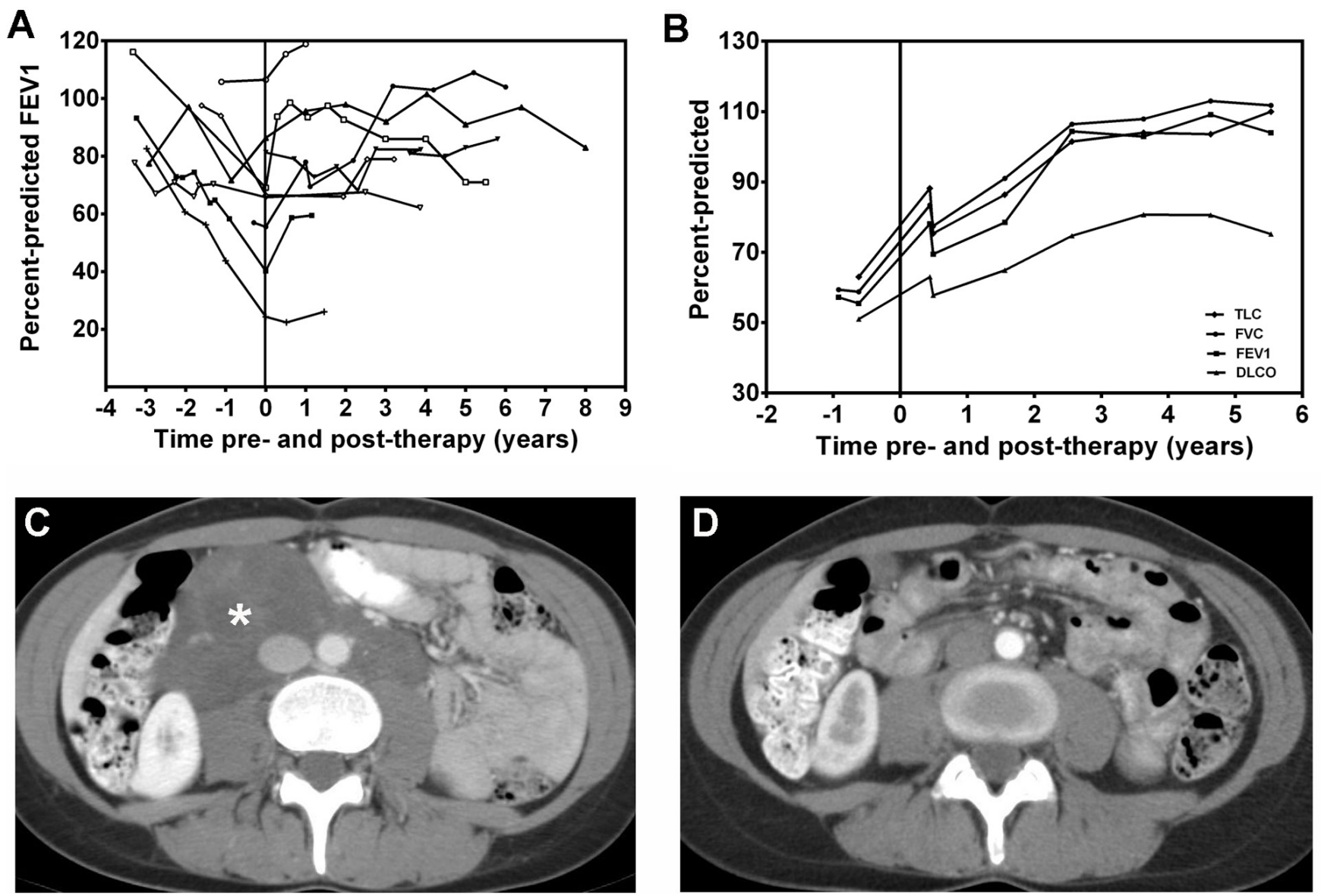

Panel A: Changes in percent-predicted forced expiratory volume in the first second $\left(\mathrm{FEV}_{1}\right)$ before and during treatment with sirolimus in nine patients with lymphangioleiomyomatosis (LAM). During treatment, FEV, either increased or stabilized. Panel B: Changes in lung function during treatment with sirolimus in one patient with chylous pleural effusions and ascites. It can be seen that total lung capacity (TLC), forced vital capacity (FVC), FEV 1 , and lung diffusion capacity $\left(\mathrm{DL}_{\mathrm{co}}\right)$, increased during sirolimus therapy and that the effect was sustained beyond five years. Panels $C$ and $\mathrm{D}$ : computed tomography (CT) scans of the abdomen show a large lymphangioleiomyoma before (white star) and after treatment with sirolimus. Complete resolution of the tumor was observed with sirolimus. Abbreviations: $\mathrm{CT}$, computed tomography; $\mathrm{DL} \mathrm{Co}_{\mathrm{CO}}$, lung diffusion capacity; FEVI, forced expiratory volume in the first second; FVC, forced vital capacity; TLC, total lung capacity. 
have symptomatic lymphangioleiomyomas, chylous pleural effusions or ascites [20,21,32]. The role of sirolimus in patients with normal or stable lung function, or very slow rates of decline, is unclear. The starting dose of sirolimus should be $1 \mathrm{mg}$ per day. Sirolimus serum levels must be monitored and dosage adjusted to attain serum trough levels between 5 and 15 nanograms per $\mathrm{ml}$ [20-22]. The most frequent adverse events associated with sirolimus therapy include stomatitis, hypercholesterolemia, upper respiratory tract infections, diarrhea, peripheral edema, acne, hypertension, headaches, leukopenia, delayed wound healing, thrombocytopenia, and proteinuria [20]. Close patient monitoring is necessary [20]. Laboratory tests including blood cells count, chemistries, urinalysis, urine protein/ creatinine ratio, and sirolimus blood levels should be performed. Pulmonary function studies should be performed at least every six months. Interaction between sirolimus and other drugs and some foods, such as grapefruit, must be monitored carefully and adjustments to the dose of sirolimus made when appropriate. Currently, it is not known whether treatment must be continued for life or whether resistance to sirolimus eventually develops. The optimal dose of sirolimus that should be employed and when it is most efficacious to initiate treatment is not known. Dosage and blood levels currently used are based on experience with sirolimus in the prevention of graft rejection in patients who have undergone organ transplantation. It is possible that lower sirolimus levels may be equally effective, especially in the treatment of lymphatic disease [33].

\section{Statins}

Activation of mTORC1 and mTORC2, and increased Rho activity, are necessary for TSC2-dependent cell proliferation and survival [34]. Absence of TSC2 causes tuberin deficiency that results in increased Rheb and RhoA activity and enhanced cell survival [34]. In TSC2deficient, rat-derived, TSC2-null ELT3 cells, downregulation of RhoA increases apoptosis, suggesting that inhibition of RhoA, which is regulated by mTORC2, may reduce cell survival [34]. Since sirolimus and everolimus only suppress mTORC1, there is a rationale for therapies targeting mTORC2 signaling [34-36].

Statins are 3-hydroxy-3-methyl-glutaryl-coenzyme-A (HMG-CoA) reductase inhibitors that inhibit geranylgeranylation of Rho GTPases, and farnesylation of the small GTPases Ras and Rheb [37]. Atorvastatin was found to inhibit the growth of $\mathrm{Tsc}^{-/}$uterine-derived leiomyoma (ELT-3) and mouse embryonic fibroblasts by reducing Rheb activity [38]. Simvastatin, another HMG-CoA reductase inhibitor, was shown to inhibit RhoA activity (see Figure 4) and the proliferation of TSC-null cells and
TSC2-null tumor growth in mice, and to promote apoptosis [34]. Combined treatment with sirolimus and simvastatin prevented recurrence of the tumors even after discontinuation of both drugs [34]. This effect was specific for simvastatin; atorvastatin did not reduce the size of liver and renal tumors in a mouse model of TSC [39]. Simvastatin was also shown to reduce alveolar space enlargement in a mouse model of LAM [40]. Further, combined with sirolimus, simvastatin blocked matrix metalloproteinase up-regulation and prevented alveolar destruction [40].

There are no data regarding the potential efficacy of simvastatin in the treatment of LAM. In one study, no correlation between statin use and angiomyolipoma response to sirolimus in patients with TSC or sporadic LAM was demonstrated [22]. In a retrospective study, the rate of decline in lung diffusion capacity in LAM patients treated with statins for hypercholesterolemia was greater than that of their matched, off-statin controls [41]. However, in this study, the number of patients treated with simvastatin was small. The effect of simvastatin combined with sirolimus or everolimus in the treatment of LAM is being investigated (NCT02061397).

\section{Anti-estrogen therapy}

Because LAM is predominantly a disease of pre-menopausal women, estrogens have been, from early on, implicated in its pathogenesis [4-6]. Oophorectomy, progesterone and gonadotrophin-releasing hormone (GnRH) analogues have all been used to treat LAM [6,42-46]. A number of case reports and uncontrolled studies have suggested beneficial effects of anti-estrogen therapies [42]. Others found no benefit from oophorectomy or progesterone therapy [43]. A reduced rate of decline in lung function in pre-menopausal patients treated with progesterone was reported [44], but a large retrospective study involving 275 patients reported no difference in disease progression between patients treated or not treated with progesterone [6]. Studies that tested the effect of GnRH analogues have also been inconclusive [45-46].

In vitro and experimental animal studies have provided a rationale for anti-estrogen therapy in LAM [47-50] (see Figure 4). LAM cells express estrogen receptors [51,52], and estradiol increases the proliferation of Eker rat-derived Tsc2-null, uterine ELT3 leiomyoma cells and the growth of xenograph subcutaneous tumors in vivo $[48,49]$. Further, estradiol also increases the number of circulating tumor cells, the survival of injected ELT3 cells, and the number of pulmonary metastasis of TSC-null cells injected subcutaneously in oophorectomized mice [49]. This effect of estradiol is associated with the activation of a mitogenactivated protein kinase (MAPK) signaling pathway that 
Figure 4. Scheme depicting some potential new targeted therapies for LAM

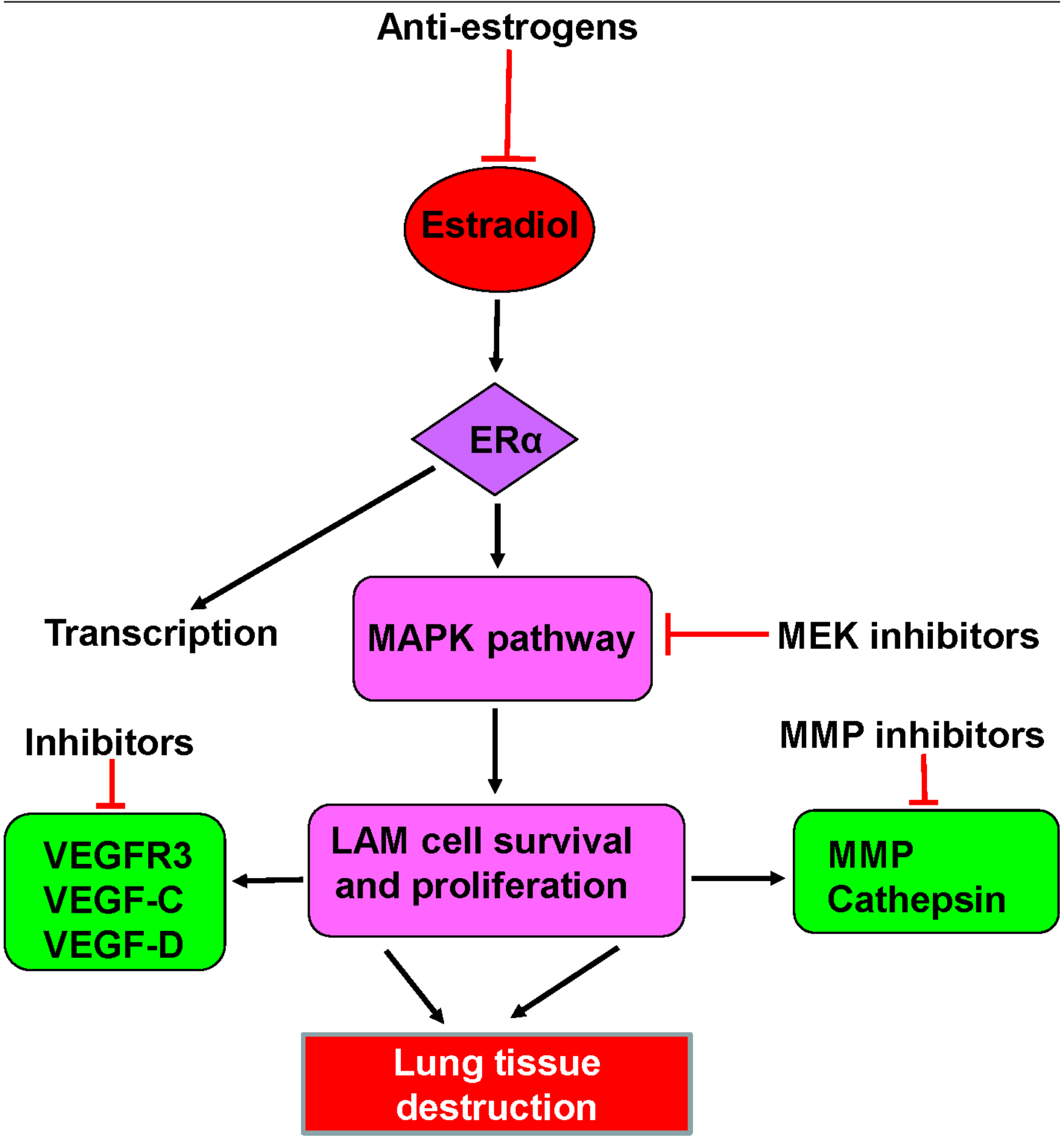

These include anti-estrogens, such the aromatase inhibitor letrozole, ER $\alpha$ blockers, MAPK kinase inhibitors, MMP inhibitors, and inhibitors of VEGF receptors and growth factors. Abbreviations: ER $\alpha$, estrogen receptor $\alpha$; ERK, extracellular signal-regulated kinases; MAPK, mitogen-activated protein kinase; MEK, MAPK/ERK; MMP, metalloproteinase; VEGF-C, vascular endothelial growth factor C; VEGF-D, vascular endothelial growth factor D; VEGFR3, vascular endothelial growth factor receptor 3. 
can be targeted in disease $[35,36,49,53,54]$. Activation of MAPK increases LAM cell resistance to apoptosis [35]. Estrogens also increase the proliferation of human TSCheterozygous and TSC-null cells, and these effects are prevented by MAPK/ERK (MEK) kinase inhibitors [49] (see Figure 4). Finally, estradiol increases matrix metalloproteinase (MMP)-2 activity in LAM cells [50]. In a xenograph tumor mouse model where estradiol induces lung metastasis of TSC-deficient cells, Faslodex, the estrogen receptor antagonist, was shown to increase animal survival by inhibiting the formation of lung metastasis [55]. Faslodex also inhibited the estrogeninduced increase in MMP-2 and extracellular matrix remodeling [55].

Clinical studies aimed at either suppressing estrogen secretion with aromatase inhibitors or with estrogen receptor antagonists are warranted, using these drugs in combination with mTOR inhibitors (see Figure 4). A clinical trial (NCT01353209) examining the effect of the aromatase inhibitor letrozole in post-menopausal women, in whom the main source of estrogens are the adrenal glands, is currently under way.

\section{Matrix metalloproteinases inhibitors}

MMPs are proteinases that degrade extracellular matrix and collagen and, by disrupting basement membranes, facilitate invasion by tumor cells [56-60]. LAM cells express immunoreactivity to MMP-2, MMP-9, and tissue inhibitors of metalloproteinase (TIMP), TIMP1, TIMP2 and TIMP3 [50,56-60]. Doxycycline, an MMP inhibitor, affects MMP production by TSC-null ELT3 cells [60,61] and inhibits MMP-2 secretion by TSC-null mouse embryonic and human LAM cells [62]. A potential role of doxycycline in the treatment of LAM has been suggested by several clinical observations $[63,64]$. Doxycycline was reported to decrease serum and urine levels of MMP-9 and MMP-2 and improve FEV F $_{1}$ in LAM patients with mild disease [63]. A two year randomized placebo-controlled study just completed in 21 patients (NCT00989742) failed to show a significant difference in rates of $\mathrm{FEV}_{1}$ decline between doxycycline and control groups, although the urinary levels of MMP-9 were decreased in the doxycycline group [65]. Currently there is no evidence that doxycycline is an effective treatment for LAM.

\section{Inhibitors of autophagy}

Autophagy is a mechanism by which cells maintain their energy homeostasis by degrading and recycling organelles, cellular debris, and damaged proteins [66-68]. These products are sequestered into autophagosomes which, after fusing with lysosomes, are degraded. The mTOR signaling pathway is a major regulator of autophagy
[67-69]. Under nutrient-rich conditions, mTORC1 promotes cell growth and autophagy by inhibiting the human homolog of ATG1 (Unc-51-like kinase 1 [ULK1]) kinase complex, comprising ULK1, autophagyrelated protein (Atg)13 and Atg17 [66,68]. Inhibition of mTORC1 increases autophagy and abrogates its inhibitory effects on phosphatidylinositol 3-kinase (PI3K) and Akt [69-71], which in turn leads to activation of mTORC1 [71,72]. Altogether, these actions lead to increased cell survival [71]. Sirolimus and everolimus, two mTORC1 inhibitors, stimulate autophagy by causing phosphorylation of Atg13, which blocks the inhibitory effects of ULK1 in the formation of autophagosomes [69-71]. Because LAM cells have low levels of autophagy, blockade of mTOR signaling with sirolimus may lead to increased LAM cell survival $[69,71]$. The antimalarial drug hydroxychloroquine blocks autophagy, inhibits the growth of cancer cells, and induces cell death [73] (see Figure 2). Sirolimus and hydroxychloroquine combined were found to be more effective than either drug alone in inhibiting the survival of TSC2-null cells and the growth of TSC2-null xenograph tumors, as well as in suppressing the spontaneous development of renal tumors in $\mathrm{Tsc2}^{+/}$ mice $[69,72]$. These observations provided a rationale for an on-going study (NCT01687179) testing the effect of hydroxychloroquine and sirolimus in LAM patients.

It has been proposed that other pharmacological agents inhibit the autophagy-promoting effect of mTORC1 inhibition by sirolimus and everolimus. A recent study showed that a combination of sirolimus and resveratrol, a polyphenol present in fruits and red wine, reduced sirolimus-induced autophagy and prevented Akt activation and apoptosis of TSC2-deficient cells [74]. Sirolimus and resveratrol in combination restored inhibition of Akt while blocking mTORC1 signaling, down-regulating autophagy and inducing apoptosis [74]. A reduction in autophagy was also shown to increase levels of Src kinase in TSC $\%$ cells and lung tissue of LAM patients [75]. Inhibition of Src reduced the invasiveness of $\mathrm{TSC}^{\%}$ cells and their colonization in the lungs [69], thus inhibiting the metastatic capacity of LAM cells. An Src inhibition trial is currently under way (NCT02116712).

These data indicate that inhibition of mTORC 1 may affect LAM cell survival and its metastatic properties. The most effective treatment for LAM may evolve into a multidrug regime consisting of an mTOR antagonist along with pharmacologic agents that abrogate the undesirable effects of mTORC1 blockade. Human studies testing the effect of these compounds in combination with mTORC1 inhibitors may provide answers to these questions. 


\section{Potential future therapies}

Several potential therapies for LAM are currently undergoing clinical trials. In addition, in vitro or animal data have suggested a potential beneficial role of other agents in the treatment of LAM [76-79].

Vascular endothelial growth factor receptor (VEGFR)-3 is a major regulator of lymphangiogenesis [54,80,81]. Immunoreactivity for vascular endothelial growth factors (VEGFs)-C and -D is present in LAM lesions and LAM cells [80]. In addition, because of the important role of lymphangiogenesis in the pathogenesis of LAM [54], and evidence that increased VEGF-D levels in the serum of LAM patients correlate with disease severity and clinical course [82], blockade of VEGFRs or anti-VEGF-D therapies are being considered as potential treatments $[54,80,81]$. In accordance, in a subcutaneous $T s c 2 \%$ tumor mouse model, sorafenib (a Raf kinase and VEGF receptor pathway inhibitor) and sirolimus together decreased tumor volume and increased survival more effectively than sirolimus alone [76]. A member of the collagen IV family, named lamstatin [83], was recently reported to have antilymphangiogenic properties. Levels of lamstatin were found to be reduced in the lungs of LAM patients [83]. Further, in vitro and in vivo studies showed that lamstatin, combined with a 17-aminoacid peptide (CP17), inhibited proliferation and migration of human lung lymphatic endothelial cells, and decreased dysplasia of the tumorassociated lymphatic network in a lung adenocarcinoma xenograph mouse model [83].

Alterations in the interferon gamma (IFN- $\gamma$ ) signaling pathway were suggested by the finding that expression of IFN- $\gamma$ is not present in angiomyolipoma from patients with TSC or LAM [77]. Treatment of Tsc1- or Tsc2-null cells with IFN- $\gamma$ was shown to induce apoptosis [78]. There was evidence of synergism between IFN- $\gamma$ and sirolimus in inducing apoptosis of these cells [78]. However, sirolimus and IFN- $\gamma$ together were not more effective than sirolimus alone against TSC-related kidney tumors in Tsc2 ${ }^{+/-}$mice [76]. A combination of an mTORC1 receptor antagonist and IFN- $\gamma$ was more effective than either single agent in decreasing the severity of kidney cystadenomas and liver hemangiomas in both $\mathrm{Tsc}^{+/-}$and $\mathrm{Tsc}^{-/}$mouse models [31]. Both drugs together were also shown to be more effective than a single agent in reducing tumor growth in a mouse model of TSC [79]. Although IFN- $\gamma$ appears not to directly inhibit the proliferation of Tsc2-null cells, or increase the inhibitory effects of sirolimus, there are data suggesting that increased expression of signal transducer and activator of transcription (STAT) 3 is present in LAM lungs and may possibly be a target for new therapies [84].
Finally, increased AMP-activated protein kinase (AMPK) activity has been reported in TSC tumors and Tsc-null cells and this may contribute to increased LAM cell survival [85]. Since Rheb controls AMPK activity independent of mTORC1 signaling $[86,87]$ and Rheb depletion decreases tumorigenesis [87], targeting Rheb may have a role in combination therapy of LAM or TSC [87].

\section{Treatment of complications Pneumothorax}

Once a patient has had a pneumothorax, the chances of having a recurrence are greater than $70 \%$ [1,88-90]. A small pneumothorax may be treated by chest tube drainage. If the air leak persists or the pneumothorax recurs, pleurodesis is recommended. A chemical or surgical pleurectomy by video-assisted thoracoscopy should be considered $[88,90]$. Chemical sclerosis with doxycycline, pleurectomy, mechanical abrasion and talc poudrage are also effective. Talc pleurodesis may result in considerable pleural scarring that may be associated with chronic pain as well as bleeding complications during removal of the native lungs at the time of transplantation $[88,90]$.

Of great concern to patients with LAM is the risk of pneumothorax associated with air travel $[25,91]$. Since cabins of commercial aircraft are pressurized only to a barometric pressure equivalent to an altitude of 1,500 to 2,500 meters, during the airplane's ascent or descent the cabin pressure falls or increases according to Boyle's law [91], leading to gas expansion or contraction within body cavities, such as lung cysts or non-functioning bullae [91]. Retrospective studies indicate that the risk of developing a pneumothorax during air travel is small, ranging from $2-4 \%[25,91,92]$. There is no evidence that pre-existing chronic loculated pneumothoraxes are associated with an increased risk of additional pneumothorax or expansion of a pre-existing pneumothorax during air travel [25]. Patients should be advised to take direct flights and to abstain from air travel if they are experiencing chest pain and/or increased dyspnea, until the presence of a pneumothorax is ruled out $[25,92,93]$.

Another potential risk associated with flying is hypoxemia [91]. An arterial blood gas obtained while breathing room air may assist in deciding whether the patient may fly without supplemental oxygen. More precisely, arterial blood gases may be measured while they breathe a low oxygen concentration that produces an inspired oxygen pressure similar to that present in pressurized cabins of commercial airplanes.

\section{Chylous effusions and lymphangioleiomyomas}

Chylous pleural effusions, ascites, and lymphangioleiomyomas may compromise respiratory function and 
cause abdominal pain, urinary frequency, obstipation, and peripheral edema [5]. Not uncommonly, patients may be misdiagnosed with a lymphoma or ovarian cancer [94-97]. The symptomatology associated with lymphatic disease in patients with LAM may cause a great deal of distress and poses difficult therapeutic problems. The least recommended therapeutic approach is continuous tube drainage of chylous pleural effusions and ascites, as this approach results in nutritional compromise, protein loss, lymphopenia, increased risk of infections, and weight loss $[21,88,90,98]$. Further, once a thoracostomy tube is placed in the pleural cavity, drainage may become continuous and pleural symphysis may become difficult. It is preferable to perform therapeutic thoracentesis when patients become symptomatic. Low fat diet, pleuro-peritoneal or peritoneal-venous shunts, treatment with somatostatin and octreotide have been employed but there is little experience with these therapies in LAM [99-102].

Surgical pleurodesis may be effective in reducing the size of the effusion, but this will not ameliorate abdominal symptoms associated with ascites and lymphangioleiomyomas. To be effective, surgical pleurodesis must be performed under conditions of reduced chyle flow. To accomplish this, patients must be placed on parenteral nutrition with a fat-free solution before, during, and after pleurodesis. The thoracostomy tube should be removed only when daily drainage volume decreases to $200 \mathrm{ml}$ or less.

A major advance in the treatment of lymphatic disease in LAM was the discovery that the mTOR inhibitor sirolimus decreased the volume of chylous effusions, the size of lymphangioleiomyomas, and ascites, cleared lung infiltrates caused by lung lymph accumulation and dramatically improved lung function [21,103]. Consequently, sirolimus is now considered to be the treatment of choice (see Figure 3). Although volume reduction or complete resolution of the lymphangioleiomyomas generally occurs within a few months, resolution of chylous effusions may take many months to more than a year [21]. While on sirolimus, therapeutic thoracentesis may be performed periodically if patients experience significant respiratory symptoms. Abdominal lymphangioleiomyomas must not be surgically removed or partially resected as this approach may result in ascites and disabling pleural effusions.

\section{Angiomyolipomas}

Angiomyolipomas occur primarily in the kidney and liver [104]. The major risk of angiomyolipomas is bleeding. Arterial embolization is recommended for the treatment of acute bleeding, severe pain, or prophylactically in patients with angiomyolipomas larger than $3-4 \mathrm{~cm}$ in diameter $[104,105]$. Resection of the kidney should be avoided unless the angiomyolipoma has an atypical radiologic appearance that raises the question of malignancy. In this case, a biopsy should be performed or the tumor should be resected $[104,106,107]$. mTORC1 inhibitors are effective in decreasing the size of renal angiomyolipomas in patients with TSC or sporadic LAM, with tumor size being reduced in about 44 to $50 \%$ of patients [22,108-110]. In one study, $42 \%$ of 79 patients with angiomyolipomas treated with everolimus responded with a 50\% reduction in tumor size after 24 weeks of therapy [110]. Following discontinuation of the drugs, the angiolipomas tended to return to their initial size. Treatment with mTOR inhibitors should probably be the initial approach for the treatment of large angiomyolipomas. Arterial embolization should be reserved for acute bleeding or for patients who do not tolerate mTOR inhibitors [104-110]. Once mTOR inhibitor therapy has begun, it must be continued because its discontinuation appears to return the tumor to its original size.

\section{Management of pregnancy}

By the time a young woman is diagnosed with LAM she may already have experienced one or more pregnancies. Not infrequently, a pneumothorax or increased dyspnea may uncover the presence of LAM $[1,111,112]$. Despite these events, of 353 pregnancies recorded in the LAM registry, $67 \%$ resulted in live birth and only about $17 \%$ had spontaneous abortion [1]. Of those who had been pregnant, 22\% experienced worsening of respiratory symptoms [1]. Patients who were diagnosed with LAM during pregnancy appear to have had more premature births, and higher frequency of dyspnea and pneumothorax than patients diagnosed either before or after pregnancy [112]. These data, along with reports of worsening symptoms during pregnancy, such as dyspnea, pneumothorax, chylous effusions or hemorrhage from angiomyolipomas [111,113-115], have raised the question as to whether LAM patients should be advised not to become pregnant.

Pregnancy should be discouraged in patients with moderate to severe disease or those in whom lung function is rapidly declining. The rationale for this recommendation is that these patients should be treated with sirolimus rather than risking further deterioration in lung function and a delay in starting therapy, because sirolimus must be discontinued prior to, and during pregnancy. Patients with mild disease who strongly desire to become pregnant should be told about its potential risks (e.g. pneumothorax, decline in lung function). They should be advised that with close medical and obstetrical supervision, others have tolerated pregnancy and 
delivered a normal child. However, at present, there is no method of predicting the outcome in terms of frequency of complications such as pneumothorax or chylothorax, and the magnitude of potential decline in lung function.

\section{Lung transplantation}

Except in advanced stages, dyspnea at rest is not a major feature of LAM [5]. Patients with an $\mathrm{FEV}_{1}$ of less than one liter and a $\mathrm{DL}_{\mathrm{CO}}$ less than $30 \%$ predicted, who are receiving supplemental oxygen, might be comfortable at rest. However, exercise and hypoxemia requiring supplemental oxygen are major factors affecting the quality of life, namely the ability of patients to conduct activities of daily living. In one study [116], preoperative $\mathrm{FEV}_{1}$ and $\mathrm{DL}_{\mathrm{CO}}$ prior to transplantation were, respectively, $20 \pm 8$ and $23 \pm 9 \%$ predicted and there was also resting hypoxemia. The average 6-minute walk test distance was 250 meters. The five-year post-transplant survival of LAM patients undergoing lung transplantation was around 69\% [116-119]. The European experience with lung transplantation in LAM is similar to that of the USA [120], but others have reported five-year survivals of around $75 \%$ [121].

Because patients with very low $\mathrm{FEV}_{1}$ and $\mathrm{DL}_{\mathrm{CO}}$ on supplemental oxygen may live for many years $[23,24]$, lung function needs to be severely compromised before lung transplantation is considered. We suggest that lung transplantation be discussed with the patient when $\mathrm{FEV}_{1}$ and $\mathrm{DL}_{\mathrm{CO}}$ are about $30 \%$ predicted, the patient is on continuous supplemental oxygen, is unable to carry out activities of daily living and has resting pulmonary hypertension. Importantly, the patient should rate her quality of life as being so poor that she wishes to undergo the additional risks associated with lung transplantation.

\section{Summary statement and conclusions}

LAM is a disease affecting women, which is associated with cystic lung destruction, and extrapulmonary manifestations consisting of abdominal angiomyolipomas and lymphangioleiomyomas. LAM presents with dyspnea, recurrent pneumothoraxes, and hemorrhages from angiomyolipomas. LAM is characterized by a reduction in breathing capacity, hypoxemia during exercise or at rest, and respiratory failure.

Not long ago, LAM was defined as a fatal disease of young women for which there was no effective therapy and the only treatment option was lung transplantation. The establishment of the National Heart, Lung, and Blood Institute (NHLBI) LAM registry and other registries worldwide have led to major progress in the characterization of the clinical features and natural history of LAM. The finding that LAM is caused by mutations of
TSC1 or TSC2 genes that encode hamartin and tuberin, two proteins with a major role in control of the mTOR signaling pathway, led to therapies targeting mTOR. Two mTORC1 inhibitors, sirolimus and everolimus, have been shown to be effective in stabilizing lung function, and reducing the size of chylous effusions, lymphangioleiomyomas, and angiomyolipomas.

Treatment with these pharmacological agents, which is generally tolerated by patients, is now the standard therapy for patients showing compromised lung function or those who have symptomatic chylous effusions and lymphangioleiomyomas or large angiomyolipomas.

In the case of angiomyolipomas, discontinuation of mTORC1 inhibitor therapy results in a return to pretherapy tumor size, suggesting that to sustain the therapeutic effects of mTORC1 inhibitors, treatment has to be continued. mTORC1 inhibition results in increased autophagy and possibly enhanced LAM cell survival, thus reducing the beneficial effects of sirolimus or everolimus. Inhibition of autophagy with hydroxychloroquine has been suggested as a new treatment for LAM, complementing inhibition of mTORC1 with sirolimus or everolimus. Such a therapeutic regimen is now undergoing clinical testing.

Deficiency of tuberin due to TSC2 mutations, as occurs in LAM, results in increased RhoA GTPase activity and increased cell survival. This effect is mediated through mTORC2 signaling. Since sirolimus and everolimus only affect the activity of mTORC1, there is a rationale for therapies targeting RhoA GTPases. Statins inhibit Rho GTPases and promote apoptosis. Simvastatin combined with sirolimus is effective in preventing lung destruction in a mouse model of LAM. Simvastatin combined with sirolimus or everolimus is currently undergoing phase 1 clinical testing in patients with LAM.

Other treatments that are being investigated are estrogen receptor blockers, aromatase inhibitors, MAPK/ERK (MEK) inhibitors and VEGFR antagonists. Blockade of VEGF receptors or anti-VEGF therapies may be of value in the treatments of LAM in view of the role of lymphangiogenesis in its pathogenesis and evidence that increased levels of VEGF-D in the serum of LAM patients correlates with disease severity and clinical course. Preclinical studies have shown that a VEGF pathway inhibitor and sirolimus together decreased tumor volume in an animal model of LAM and increased survival more effectively than sirolimus alone.

We conclude that, as in the case of cancer, LAM (which is considered a low grade malignancy) may be best treated 
with multiple drugs targeting signaling pathways considered important in the pathogenesis of LAM.

\section{Abbreviations}

Akt, protein kinase B; AMPK, AMP-activated protein kinase; Atg, autophagy-related protein; $\mathrm{DL}_{\mathrm{CO}}$, lung diffusion capacity; FEV1, forced expiratory volume in the first second; GnRH, gonadotrophin-releasing hormone; HMB, human melanin black antibody; IFN- $\gamma$, interferon gamma; LAM, lymphangioleiomyomatosis; MAPK, mitogen-activated protein kinase; MMP, metalloproteinase; mTOR, mammalian target of rapamycin; mTORC1, mTOR complex 1; mTORC2, mTOR complex 2; PI3K, phosphoinositide-3-kinase; Rheb, Ras homolog enriched in brain GTPase-activating protein; TIMP, tissue inhibitor of metalloproteinase; TSC, tuberous sclerosis complex; ULK1, Unc-51-like kinase 1; VEGF, vascular endothelial growth factor; VEGFR, vascular endothelial growth factor receptor.

\section{Disclosures}

The authors declare that they have no disclosures.

\section{Acknowledgments}

The authors thank Gustavo Pacheco-Rodriguez PhD for his assistance with the preparation of the figures. Authors were supported by the Intramural Research Program, National Institutes of Health, National Heart, Lung and Blood Institute.

\section{References}

I. Ryu JH, Moss J, Beck GJ, Lee J, Brown KK, Chapman JT, Finlay GA, Olson EJ, Ruoss SJ, Maurer JR, Raffin TA, Peavy HH, McCarthy K, Taveira-Dasilva A, McCormack FX, Avila NA, Decastro RM, Jacobs SS, Stylianou M, Fanburg BL: The NHLBI lymphangioleiomyomatosis registry: characteristics of $\mathbf{2 3 0}$ patients at enrollment. Am J Respir Crit Care Med 2006, 173:105-II.

2. Matsui K, Tatsuguchi A, Valencia J, Yu Zx, Bechtle J, Beasley MB, Avila N, Travis WD, Moss J, Ferrans VJ: Extrapulmonary lymphangioleiomyomatosis (LAM): clinicopathologic features in 22 cases. Hum Pathol 2000, 31:1242-8.

3. Ferrans VJ, Yu Zx, Nelson WK, Valencia JC, Tatsuguchi A, Avila NA, Riemenschn W, Matsui K, Travis WD, Moss J: Lymphangioleiomyomatosis (LAM): a review of clinical and morphological features. J Nippon Med Sch 2000, 67:3II-29.

4. McCormack FX: Lymphangioleiomyomatosis: a clinical update. Chest 2008, I33:507-16.

5. Taveira-DaSilva AM, Pacheco-Rodriguez G, Moss J: The natural history of lymphangioleiomyomatosis: markers of severity, rate of progression and prognosis. Lymphat Res Biol 2010, 8:9-19.

6. Taveira-DaSilva AM, Stylianou MP, Hedin CJ, Hathaway O, Moss J: Decline in lung function in patients with lymphangioleiomyomatosis treated with or without progesterone. Chest 2004, 126:1867-74.

7. Taveira-DaSilva AM, Stylianou MP, Hedin CJ, Kristof AS, Avila NA, Rabel A, Travis WD, Moss J: Maximal oxygen uptake and severity of disease in lymphangioleiomyomatosis. Am J Respir Crit Care Med 2003, 168:1427-31.
8. Cudzilo CJ, Szczesniak RD, Brody AS, Rattan MS, Krueger DA, Bissler JJ, Franz DN, McCormack FX, Young LR: Lymphangioleiomyomatosis screening in women with tuberous sclerosis. Chest 20I3, 144:578-85.

\section{FlOOOPrime}

9. Curatolo P, Bombardieri R, Jozwiak S: Tuberous sclerosis. Lancet 2008, 372:657-68.

10. Harknett EC, Chang, WYC, Byrnes S, Johnson J, Lazor R, Cohen MM, Gray B, Geiling S, Telford H, Tattersfield AE, Hubbard RB, Johnson SR: Use of variability in national and regional data to estimate the prevalence of lymphangioleiomyomatosis. QJM 20II, 104:97I-9.

\section{FlOOOPrime
RECOMMENDED}

II. Smolarek TA, Wessner LL, McCormack FX, Mylet JC, Menon AG, Henske EP: Evidence that lymphangiomyomatosis is caused by TSC2 mutations: chromosome $16 \mathrm{p} / 3$ loss of heterozygosity in angiomyolipomas and lymph nodes from women with lymphangiomyomatosis. Am J Hum Genet 1998, 62:810-5.

12. Carsillo T, Astrinidis A, Henske EP: Mutations in the tuberous sclerosis complex gene TSC2 are a cause of sporadic pulmonary lymphangioleiomyomatosis. Proc Natl Acad Sci USA 2000, 97:6085-90.

13. Yu J, Astrinidis A, Henske EP: Chromosome 16 loss of heterozygosity in tuberous sclerosis and sporadic lymphangiomyomatosis. Am J Respir Crit Care Med 2001, 164:1537-40.

14. Crooks DM, Pacheco-Rodriguez G, Decastro RM, McCoy JP, Wang J, Kumaki F, Darling T, Moss J: Molecular and genetic analysis of disseminated neoplastic cells in lymphangioleiomyomatosis. Proc Natl Acad Sci USA 2004, I0 I: 17462-7.

15. Cai X, Pacheco-Rodriguez G, Fan Q, Haughey M, Samsel L, ElChemaly S, Wu H, McCoy JP, Steagall WK, Lin J, Darling TN, Moss J: Phenotypic characterization of disseminated cells with TSC2 loss of heterozygosity in patients with lymphangioleiomyomatosis. Am J Respir Crit Care Med 2010, 182:1410-8.

16. Bittmann I, Rolf B, Amann G, Löhrs U: Recurrence of lymphangioleiomyomatosis after single lung transplantation: new insights into pathogenesis. Hum Pathol 2003, 34:95-8.

17. Karbowniczek M, Astrinidis A, Balsara BR, Testa JR, Lium JH, Colby TV, McCormack FX, Henske EP: Recurrent lymphangiomyomatosis after transplantation: genetic analyses reveal a metastatic mechanism. Am J Respir Crit Care Med 2003, 167:976-82.

18. Mitani K, Kumasaka T, Takemura H, Hayashi T, Gunji Y, Kunogi M, Akiyoshi T, Takahashi K, Suda K, Seyama K: Cytologic, immunocytochemical and ultrastructural characterization of lymphangioleiomyomatosis cell clusters in chylous effusions of patients with lymphangioleiomyomatosis. Acta Cytol 2009, 53:402-9.

19. Zoncu R, Efeyan A, Sabatini DM: mTOR: from growth signal integration to cancer, diabetes and ageing. Nat Rev Mol Cell Biol 2011, I 2:21-35.

20. McCormack FX, Inoue $Y$, Moss J, Singer LG, Strange $C$, Nakata $K$, Barker AF, Chapman JT, Brantly ML, Stocks JM, Brown KK, Lynch JP, Goldberg HJ, Young LR, Kinder BW, Downey GP, Sullivan EJ, Colby TV, McKay RT, Cohen MM, Korbee L, Taveira-DaSilva AM, Lee H, Krischer JP, Trapnell BC: Efficacy and safety of sirolimus in lymphangioleiomyomatosis. N Engl J Med 20II, 364:1595-606.

\section{FlOOOPrime}

RECOMMENDED

21. Taveira-DaSilva AM, Hathaway O, Stylianou M, Moss J: Changes in lung function and chylous effusions in patients with lymphangioleiomyomatosis treated with sirolimus. Ann Intern Med 201 I, I54:797-805, W-292-3.

\section{FlOOOPrime} RECOMMENDED

22. Bissler JJ, McCormack FX, Young LR, Elwing JM, Chuck G, Leonard JM, Schmithorst VJ, Laor T, Brody AS, Bean J, Salisbury S, 
Franz DN: Sirolimus for angiomyolipoma in tuberous sclerosis complex or lymphangioleiomyomatosis. N Engl J Med 2008, 358: $|40-5|$.

\section{FlOOOPrime RECOMMENDED}

23. Cohen MM, Pollock-BarZiv S, Johnson SR: Emerging clinical picture of lymphangioleiomyomatosis. Thorax 2005, 60:875-9.

\section{FlOOOPrime \\ RECOMMENDED}

24. Oprescu N, McCormack FX, Byrnes S, Kinder BW: Clinical predictors of mortality and cause of death in lymphangioleiomyomatosis: a population-based registry. Lung 2013, 191:35-42.

\section{FlOOOPrime} RECOMMENDE

25. Taveira-DaSilva AM, Burstein D, Hathaway OM, Fontana JR, Gochuico BR, Avila NA, Moss J: Pneumothorax after air travel in lymphangioleiomyomatosis, idiopathic pulmonary fibrosis, and sarcoidosis. Chest 2009, I36:665-70.

26. Rosner M, Hanneder M, Siegel N, Valli A, Hengstschläger M: The tuberous sclerosis gene products hamartin and tuberin are multifunctional proteins with a wide spectrum of interacting partners. Mutat Res 2008, 658:234-46.

27. Sarbassov DD, Ali SM, Kim D, Guertin DA, Latek RR, ErdjumentBromage H, Tempst P, Sabatini DM: Rictor, a novel binding partner of $\mathrm{mTOR}$, defines a rapamycin-insensitive and raptor-independent pathway that regulates the cytoskeleton. Curr Biol 2004, 14:1296-302.

\section{FlOOOPrime}

\section{RECOMMENDED}

28. Huang J, Manning BD: A complex interplay between Akt, TSC2 and the two mTOR complexes. Biochem Soc Trans 2009, 37:2 17-22.

29. Krymskaya VP, Goncharova EA: PI3K/mTORCI activation in hamartoma syndromes: therapeutic prospects. Cell Cycle 2009, 8:403-I3.

30. Kenerson H, Dundon TA, Yeung RS: Effects of rapamycin in the Eker rat model of tuberous sclerosis complex. Pediatr Res 2005, 57:67-75.

31. Lee L, Sudentas P, Donohue B, Asrican K, Worku A, Walker V, Sun Y, Schmidt K, Albert MS, El-Hashemite N, Lader AS, Onda H, Zhang H, Kwiatkowski DJ, Dabora SL: Efficacy of a rapamycin analog (CCl779) and IFN-gamma in tuberous sclerosis mouse models. Genes Chromosomes Cancer 2005, 42:213-27.

32. Neurohr C, Hoffmann AL, Huppmann P, Herrera VA, Ihle F, Leuschner $S$, Wulffen $W$ von, Meis T, Baezner C, Leuchte $H$, Baumgartner R, Zimmermann G, Behr J: Is sirolimus a therapeutic option for patients with progressive pulmonary lymphangioleiomyomatosis? Respir Res 20I I, I 2:66.

\section{FlOOOPrime}

\section{RECOMMENDED}

33. Ando K, Kurihara M, Kataoka H, Ueyama M, Togo S, Sato T, Doi T, Iwakami S, Takahashi K, Seyama K, Mikami M: Efficacy and safety of low-dose sirolimus for treatment of lymphangioleiomyomatosis. Respir Investig 2013, 5 I:I75-83.

34. Goncharova EA, Goncharov DA, Li H, Pimtong W, Lu S, Khavin I, Krymskaya VP: $\mathbf{m T O R C 2}$ is required for proliferation and survival of TSC2-null cells. Mol Cell Biol 20I I, 31:2484-98.

\section{FlOOOPrime \\ RECOMMENDED}

35. Hammes SR, Krymskaya VP: Targeted approaches toward understanding and treating pulmonary lymphangioleiomyomatosis (LAM). Horm Cancer 2013, 4:70-7.

\section{FlOOOPrime}

\section{RECOMMENDED}

36. Henske EP, McCormack FX: Lymphangioleiomyomatosis - a wolf in sheep's clothing. J Clin Invest 2012, | 22:3807-16.

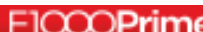

37. Atochina-Vasserman EN, Goncharov DA, Volgina AV, Milavec M, James ML, Krymskaya VP: Statins in lymphangioleiomyomatosis. Simvastatin and atorvastatin induce differential effects on tuberous sclerosis complex 2-null cell growth and signaling. Am J Respir Cell Mol Biol 2013, 49:704-9.

38. Finlay GA, Malhowski AJ, Liu Y, Fanburg BL, Kwiatkowski DJ, Toksoz D: Selective inhibition of growth of tuberous sclerosis complex 2 null cells by atorvastatin is associated with impaired Rheb and Rho GTPase function and reduced mTOR/S6 kinase activity. Cancer Res 2007, 67:9878-86.

39. Finlay GA, Malhowski AJ, Polizzi K, Malinowska-Kolodziej I, Kwiatkowski DJ: Renal and liver tumors in Tsc2(+/-) mice, a model of tuberous sclerosis complex, do not respond to treatment with atorvastatin, a 3-hydroxy-3-methylglutaryl coenzyme A reductase inhibitor. Mol Cancer Ther 2009, 8:1799-807.

40. Goncharova EA, Goncharov DA, Fehrenbach M, Khavin I, Ducka B, Hino O, Colby TV, Merrilees MJ, Haczku A, Albelda SM, Krymskaya VP: Prevention of alveolar destruction and airspace enlargement in a mouse model of pulmonary lymphangioleiomyomatosis (LAM). Sci Transl Med 2012, 4:I54ral 34.

\section{FlOOOPrime}

\section{RECOMMENDED}

4I. El-Chemaly S, Taveira-DaSilva A, Stylianou MP, Moss J: Statins in lymphangioleiomyomatosis: a word of caution. Eur Respir J 2009, 34:513-4.

42. Eliasson AH, Phillips YY, Tenholder MF: Treatment of lymphangioleiomyomatosis. A meta-analysis. Chest 1989, 96:1352-5.

43. Taylor JR, Ryu J, Colby TV, Raffin TA: Lymphangioleiomyomatosis. Clinical course in 32 patients. N Engl J Med 1990, 323: $1254-60$.

44. Johnson SR, Tattersfield AE: Decline in lung function in lymphangioleiomyomatosis: relation to menopause and progesterone treatment. Am J Respir Crit Care Med 1999, 160:628-33.

45. Harari S, Cassandro R, Chiodini I, Chiodini J, Taveira-DaSilva AM, Moss J: Effect of a gonadotrophin-releasing hormone analogue on lung function in lymphangioleiomyomatosis. Chest 2008, 133:448-54.

46. Baldi BG, Medeiros Junior P, Pimenta SP, Lopes RI, Kairalla RA, Carvalho, Carlos Roberto Ribeiro: Evolution of pulmonary function after treatment with goserelin in patients with lymphangioleiomyomatosis. J Bras Pneumol 201 I, 37:375-9.

47. Howe SR, Gottardis MM, Everitt JI, Walker C: Estrogen stimulation and tamoxifen inhibition of leiomyoma cell growth in vitro and in vivo. Endocrinology 1995, 136:4996-5003.

48. $\mathrm{Yu}$ J, Astrinidis A, Howard S, Henske EP: Estradiol and tamoxifen stimulate LAM-associated angiomyolipoma cell growth and activate both genomic and nongenomic signaling pathways. Am J Physiol Lung Cell Mol Physiol 2004, 286:L694-700.

49. Yu J], Robb VA, Morrison TA, Ariazi EA, Karbowniczek M, Astrinidis A, Wang C, Hernandez-Cuebas L, Seeholzer LF, Nicolas E, Hensley H, Jordan VC, Walker CL, Henske EP: Estrogen promotes the survival and pulmonary metastasis of tuberinnull cells. Proc Natl Acad Sci USA 2009, 106:2635-40.

\section{FlOOOPrime}

50. Glassberg MK, Elliot SJ, Fritz J, Catanuto P, Potier M, Donahue R, Stetler-Stevenson W, Karl M: Activation of the estrogen receptor contributes to the progression of pulmonary lymphangioleiomyomatosis via matrix metalloproteinaseinduced cell invasiveness. J Clin Endocrinol Metab 2008, 93:1625-33.

51. Berger U, Khaghani A, Pomerance A, Yacoub MH, Coombes RC: Pulmonary lymphangioleiomyomatosis and steroid receptors. An immunocytochemical study Am J Clin Pathol 1990, 93:609-I4.

52. Ohori NP, Yousem SA, Sonmez-Alpan E, Colby TV: Estrogen and progesterone receptors in lymphangioleiomyomatosis, epithelioid hemangioendothelioma, and sclerosing hemangioma of the lung. Am J Clin Pathol I99|, 96:529-35. 
53. El-Chemaly S, Henske EP: Towards personalised therapy for lymphangioleiomyomatosis: lessons from cancer. Eur Respir Rev 2014, 23:30-5.

\section{FlOOOPrime}

\section{RECOMMENDED}

54. Yu J, Henske EP: mTOR activation, lymphangiogenesis, and estrogen-mediated cell survival: the "perfect storm" of prometastatic factors in LAM pathogenesis. Lymphat Res Biol 2010, 8:43-9.

\section{FlOOOPrime \\ RECOMMENDED}

55. Li C, Zhou X, Sun Y, Zhang E, Mancini JD, Parkhitko A, Morrison TA, Silverman EK, Henske EP, Yu Jl: Faslodex inhibits estradiolinduced extracellular matrix dynamics and lung metastasis in a model of lymphangioleiomyomatosis. Am J Respir Cell Mol Biol 2013, 49:135-42.

\section{FlOOOPrime RECOMMENDED}

56. Matsui K, Takeda K, Yu Zx, Travis WD, Moss J, Ferrans VJ: Role for activation of matrix metalloproteinases in the pathogenesis of pulmonary lymphangioleiomyomatosis. Arch Pathol Lab Med 2000, 124:267-75.

57. Krymskaya VP, Shipley JM: Lymphangioleiomyomatosis: a complex tale of serum response factor-mediated tissue inhibitor of metalloproteinase-3 regulation. Am J Respir Cell Mol Biol 2003, 28:546-50.

58. Papakonstantinou E, Dionyssopoulos A, Aletras AJ, Pesintzaki C, Minas A, Karakiulakis G: Expression of matrix metalloproteinases and their endogenous tissue inhibitors in skin lesions from patients with tuberous sclerosis. J Am Acad Dermatol 2004, 51:526-33.

59. Zhe $X$, Yang $Y$, Jakkaraju S, Schuger L: Tissue inhibitor of metalloproteinase-3 downregulation in lymphangioleiomyomatosis: potential consequence of abnormal serum response factor expression. Am J Respir Cell Mol Biol 2003, 28:504-II.

60. Odajima $\mathrm{N}$, Betsuyaku $\mathrm{T}$, Nasuhara $\mathrm{Y}$, Inoue H, Seyama K, Nishimura M: Matrix metalloproteinases in blood from patients with LAM. Respir Med 2009, 103:124-9.

61. Chang, William YC, Clements D, Johnson SR: Effect of doxycycline on proliferation, MMP production, and adhesion in LAMrelated cells. Am J Physiol Lung Cell Mol Physiol 2010, 299:L393-400.

62. Moir LM, Ng HY, Poniris MH, Santa T, Burgess JK, Oliver, BGG, Krymskaya VP, Black JL: Doxycycline inhibits matrix metalloproteinase-2 secretion from TSC2-null mouse embryonic fibroblasts and lymphangioleiomyomatosis cells. $\mathrm{Br} J$ Pharmacol 20II, 164:83-92.

63. Moses MA, Harper J, Folkman J: Doxycycline treatment for lymphangioleiomyomatosis with urinary monitoring for MMPs. N Engl J Med 2006, 354:2621-2.

64. Pimenta SP, Baldi BG, Acencio, Milena Marques Pagliarelli, Kairalla RA, Carvalho, Carlos Roberto Ribeiro: Doxycycline use in patients with lymphangioleiomyomatosis: safety and efficacy in metalloproteinase blockade. J Bras Pneumol 201 I, 37:424-30.

65. Chang, William YC, Cane JL, Kumaran M, Lewis S, Tattersfield AE, Johnson SR: A 2-year randomised placebo-controlled trial of doxycycline for lymphangioleiomyomatosis. Eur Respir ] 2014, 43: III4-23.

66. Yang Z], Chee CE, Huang S, Sinicrope FA: The role of autophagy in cancer: therapeutic implications. Mol Cancer Ther 2011, I0:|533-4I.

67. Pattingre S, Espert L, Biard-Piechaczyk M, Codogno P: Regulation of macroautophagy by mTOR and Beclin I complexes. Biochimie 2008, 90:3|3-23.

68. Jiang P, Mizushima N: Autophagy and human diseases. Cell Res 2014, 24:69-79.
69. Yu J, Parkhitko AA, Henske EP: Mammalian target of rapamycin signaling and autophagy: roles in lymphangioleiomyomatosis therapy. Proc Am Thorac Soc 2010, 7:48-53.

\section{FlOOOPrime}

\section{RECOMMENDED}

70. Takeuchi H, Kondo Y, Fujiwara K, Kanzawa T, Aoki H, Mills GB, Kondo S: Synergistic augmentation of rapamycin-induced autophagy in malignant glioma cells by phosphatidylinositol 3-kinase/protein kinase B inhibitors. Cancer Res 2005 , 65:3336-46.

7I. Yu J, Parkhitko A, Henske EP: Autophagy: an 'Achilles' heel of tumorigenesis in TSC and LAM. Autophagy 20II, 7:1400-I.

72. Parkhitko A, Myachina F, Morrison TA, Hindi KM, Auricchio N, Karbowniczek M, Wu J], Finkel T, Kwiatkowski DJ, Yu J], Henske EP: Tumorigenesis in tuberous sclerosis complex is autophagy and p62/sequestosome I (SOSTMI)-dependent. Proc Natl Acad Sci USA 20II, I08: 12455-60.

\section{FlOOOPrime
RECOMMENDED}

73. Solomon VR, Lee $\mathrm{H}$ : Chloroquine and its analogs: a new promise of an old drug for effective and safe cancer therapies. Eur J Pharmacol 2009, 625:220-33.

74. Alayev A, Sun Y, Snyder RB, Berger SM, Yu JJ, Holz MK: Resveratrol prevents rapamycin-induced upregulation of autophagy and selectively induces apoptosis in TSC2-deficient cells. Cell Cycle 2014, 13:37|-82

FlOOOPrime

75. Tyryshkin A, Bhattacharya A, Eissa NT: SRC kinase is a novel therapeutic target in lymphangioleiomyomatosis. Cancer Res 20I4, 74:1996-2005.

\section{FlOOOPrime} RECOMMENDED

76. Lee N, Woodrum CL, Nobil AM, Rauktys AE, Messina MP, Dabora SL: Rapamycin weekly maintenance dosing and the potential efficacy of combination sorafenib plus rapamycin but not atorvastatin or doxycycline in tuberous sclerosis preclinical models. BMC Pharmacol 2009, 9:8.

77. El-Hashemite $\mathrm{N}$, Zhang $\mathrm{H}$, Walker $\mathrm{V}$, Hoffmeister $\mathrm{KM}$, Kwiatkowski D]: Perturbed IFN-gamma-Jak-signal transducers and activators of transcription signaling in tuberous sclerosis mouse models: synergistic effects of rapamycin-IFN-gamma treatment. Cancer Res 2004, 64:3436-43.

\section{FlOOOPrime}

\section{RECOMMENDED}

78. El-Hashemite N, Kwiatkowski DJ: Interferon-gamma-Jak-Stat signaling in pulmonary lymphangioleiomyomatosis and renal angiomyolipoma: a potential therapeutic target. $\mathrm{Am} J$ Respir Cell Mol Biol 2005, 33:227-30.

\section{FlOOOPrime \\ RECOMMENDED}

79. Lee L, Sudentas P, Dabora SL: Combination of a rapamycin analog $(\mathrm{CCl}-779)$ and interferon-gamma is more effective than single agents in treating a mouse model of tuberous sclerosis complex. Genes Chromosomes Cancer 2006, 45:933-44.

80. Glasgow CG, Steagall WK, Taveira-Dasilva A, Pacheco-Rodriguez G, Cai X, El-Chemaly S, Moses M, Darling T, Moss J: Lymphangioleiomyomatosis (LAM): molecular insights lead to targeted therapies. Respir Med 2010, 104(Suppl I):S45-58.

8I. Meraj R, Wikenheiser-Brokamp KA, Young LR, McCormack FX: Lymphangioleiomyomatosis: new concepts in pathogenesis, diagnosis, and treatment. Semin Respir Crit Care Med 2012, 33:486-97.

82. Young L, Lee $H$, Inoue $Y$, Moss J, Singer LG, Strange C, Nakata K, Barker AF, Chapman JT, Brantly ML, Stocks JM, Brown KK, Lynch JP, Goldberg HJ, Downey GP, Swigris JJ, Taveira-DaSilva AM, Krischer JP, Trapnell BC, McCormack FX: Serum VEGF-D a concentration as 
a biomarker of lymphangioleiomyomatosis severity and treatment response: a prospective analysis of the Multicenter International Lymphangioleiomyomatosis Efficacy of Sirolimus (MILES) trial. Lancet Respir Med 2013, I:445-52.

\section{FlOOOPRime}

83. Weckmann M, Moir LM, Heckman CA, Black JL, Oliver BG, Burgess JK: Lamstatin-a novel inhibitor of lymphangiogenesis derived from collagen IV. J Cell Mol Med 2012, 16:3062-73.

84. Goncharova EA, Goncharov DA, Damera G, Tliba O, Amrani Y, Panettieri RA, Krymskaya VP: Signal transducer and activator of transcription 3 is required for abnormal proliferation and survival of TSC2-deficient cells: relevance to pulmonary lymphangioleiomyomatosis. Mol Pharmacol 2009, 76:766-77.

\section{FlOOOPrime \\ RECOMMENDED}

85. Burgstaller S, Rosner M, Lindengrün C, Hanneder M, Siegel N, Valli A, Fuchs C, Hengstschläger M: Tuberin, p27 and mTOR in different cells. Amino Acids 2009, 36:297-302.

86. Lacher MD, Pincheira RJ, Castro AF: Consequences of interrupted Rheb-to-AMPK feedback signaling in tuberous sclerosis complex and cancer. Small GTPases 20II, 2:2I I-6.

87. Makovski V, Haklai R, Kloog Y: Farnesylthiosalicylic acid (salirasib) inhibits Rheb in TSC2-null ELT3 cells: a potential treatment for lymphangioleiomyomatosis. Int J Cancer 2012, I30: 1420-9.

88. Almoosa KF, McCormack FX, Sahn SA: Pleural disease in lymphangioleiomyomatosis. Clin Chest Med 2006, 27:355-68.

89. Steagall WK, Glasgow CG, Hathaway OM, Avila NA, TaveiraDaSilva AM, Rabel A, Stylianou MP, Lin J, Chen X, Moss J: Genetic and morphologic determinants of pneumothorax in lymphangioleiomyomatosis. Am J Physiol Lung Cell Mol Physiol 2007, 293:L800-8

90. Almoosa KF, Ryu JH, Mendez J, Huggins JT, Young LR, Sullivan EJ, Maurer J, McCormack FX, Sahn SA: Management of pneumothorax in lymphangioleiomyomatosis: effects on recurrence and lung transplantation complications. Chest 2006, I29:1274-8I.

91. Managing passengers with respiratory disease planning air travel: British Thoracic Society recommendations. Thorax 2002, 57:289-304.

92. $\mathrm{Hu} X$, Cowl CT, Baqir M, Ryu JH: Air travel and pneumothorax. Chest 2014, 145:688-94.

93. Bunch A, Duchateau F, Verner L, Truwit J, O'Connor R, Brady W: Commercial air travel after pneumothorax: a review of the literature. Air Med J 20I3, 32:268-74.

94. Jaiswal VR, Baird J, Fleming J, Miller DS, Sharma S, Molberg K: Localized retroperitoneal lymphangioleiomyomatosis mimicking malignancy. A case report and review of the literature. Arch Pathol Lab Med 2003, I 27:879-82.

95. Lu H, Wang J, Tsang Y, Lin M, Li Y: Lymphangioleiomyomatosis initially presenting with abdominal pain: a case report. Clin Imaging 2003, 27:166-70.

96. Wong Y, Yeung T, Chu WC: Atypical presentation of lymphangioleiomyomatosis as acute abdomen: CT diagnosis. AJR Am J Roentgenol 2003, I8I:284-5.

97. Avila NA, Dwyer AJ, Moss J: Imaging features of lymphangioleiomyomatosis: diagnostic pitfalls. AJR Am J Roentgenol 201I, 196:982-6.

98. Ryu JH, Doerr CH, Fisher SD, Olson EJ, Sahn SA: Chylothorax in lymphangioleiomyomatosis. Chest 2003, 123:623-7.

99. Kimura M, Morikawa T, Takeuchi K, Furuie H, Fukimura M, Mikami R, Kakuta Y, Kawamura S, Tashiro Y: [Lymphangiomyomatosis with chylous ascites treatment successfully by peritoneo-venous shunting]. Nihon Kyobu Shikkan Gakkai Zasshi 1996, 34:557-62.

100. Makino Y, Shimanuki Y, Fujiwara N, Morio Y, Sato K, Yoshimoto J, Gunji Y, Suzuki T, Sasaki S, Iwase A, Kawasaki S, Takahashi K, Seyama K: Peritoneovenous shunting for intractable chylous ascites complicated with lymphangioleiomyomatosis. Intern Med 2008, 47:28I-5.

10I. Mikroulis D, Didilis V, Bitzikas G, Bougioukas G: Octreotide in the treatment of chylothorax. Chest 2002, I 2 1:2079-80; author reply 2080-I.

102. Makrilakis K, Pavlatos S, Giannikopoulos G, Toubanakis C, Katsilambros N: Successful octreotide treatment of chylous pleural effusion and lymphedema in the yellow nail syndrome. Ann Intern Med 2004, I 41:246-7.

103. Piha-Paul SA, Hong DS, Kurzrock R: Response of lymphangioleiomyomatosis to a mammalian target of rapamycin inhibitor (temsirolimus) -based treatment. J Clin Oncol 201I, 29:e333-5.

\section{FlOOOPrime
RECOMMENDED}

104. Bissler JJ, Kingswood JC: Renal angiomyolipomata. Kidney Int 2004, 66:924-34.

105. Williams JM, Racadio JM, Johnson ND, Donnelly LF, Bissler J]: Embolization of renal angiomyolipomata in patients with tuberous sclerosis complex. Am J Kidney Dis 2006, 47:95-102.

106. Wong IY, Shortliffe LD: The management of renal angiomyolipomas in a patient with tuberous sclerosis. Nat Clin Pract Urol 2009, 6: 168-72.

107. Sooriakumaran P, Gibbs P, Coughlin G, Attard V, Elmslie F, Kingswood C, Taylor J, Corbishley C, Patel U, Anderson C: Angiomyolipomata: challenges, solutions, and future prospects based on over 100 cases treated. BJU Int 2010, 105:I0I-6.

108. Davies DM, de Vries, Petrus J, Johnson SR, McCartney DL, Cox JA, Serra AL, Watson PC, Howe CJ, Doyle T, Pointon K, Cross JJ, Tattersfield AE, Kingswood JC, Sampson JR: Sirolimus therapy for angiomyolipoma in tuberous sclerosis and sporadic lymphangioleiomyomatosis: a phase 2 trial. Clin Cancer Res 2011, 17:407|-8I.

\section{FIOOOPrime}

109. Dabora SL, Franz DN, Ashwal S, Sagalowsky A, DiMario FJ, Miles D, Cutler D, Krueger D, Uppot RN, Rabenou R, Camposano S, Paolini J, Fennessy F, Lee N, Woodrum C, Manola J, Garber J, Thiele EA: Multicenter phase 2 trial of sirolimus for tuberous sclerosis: kidney angiomyolipomas and other tumors regress and VEGF- D levels decrease. PLOS ONE 20I I, 6:e23379.

\section{FlOOOPrime
RECOMMENDED}

I 10. Bissler JJ, Kingswood JC, Radzikowska E, Zonnenberg BA, Frost M, Belousova E, Sauter M, Nonomura N, Brakemeier S, de Vries, Petrus J, Whittemore VH, Chen D, Sahmoud T, Shah G, Lincy J, Lebwohl D, Budde K: Everolimus for angiomyolipoma associated with tuberous sclerosis complex or sporadic lymphangioleiomyomatosis (EXIST-2): a multicentre, randomised, double-blind, placebo-controlled trial. Lancet 2013, 381:8I7-24.

\section{FlOOOPrime

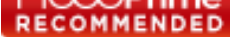

III. Johnston CR, O'Donnell ME, Sayed Ahmed WA, Ahmed WA, Hunter A, Graham AN: Bilateral pneumothorax in pregnancy unmasking lymphangioleiomyomatosis. Ir J Med Sci 201I, 180:933-4.

112. Cohen MM, Freyer AM, Johnson SR: Pregnancy experiences among women with lymphangioleiomyomatosis. Respir Med 2009, 103:766-72.

113. Iruloh C, Keriakos R, Smith DJ, Cleveland T: Renal angiomyolipoma and lymphangioleiomyomatosis in pregnancy. J Obstet Gynaecol 2013, 33:542-6.

I14. McLoughlin L, Thomas G, Hasan K: Pregnancy and lymphangioleiomyomatosis: anaesthetic management. Int J Obstet Anesth 2003, 12:40-4.

I I5. Fujimoto M, Ohara N, Sasaki H, Funakoshi T, Morita H, Deguchi M, Maruo T: Pregnancy complicated with pulmonary 
lymphangioleiomyomatosis: case report. Clin Exp Obstet Gynecol 2005, 32:199-200.

116. Pechet TT, Meyers BF, Guthrie TJ, Battafarano RJ, Trulock EP, Cooper JD, Patterson GA: Lung transplantation for lymphangioleiomyomatosis. J Heart Lung Transplant 2004, 23:30I-8.

117. Kpodonu J, Massad MG, Chaer RA, Caines A, Evans A, Snow NJ, Geha AS: The US experience with lung transplantation for pulmonary lymphangioleiomyomatosis. J Heart Lung Transplant 2005, 24:1247-53.

I 18. Maurer JR, Ryu J, Beck G, Moss J, Lee J, Finlay G, Brown K, Chapman J, McMahan J, Olson E, Ruoss S, Sherer S: Lung transplantation in the management of patients with lymphangioleiomyomatosis: baseline data from the NHLBI LAM Registry. J Heart Lung Transplant 2007, 26:1293-9.
I19. Reynaud-Gaubert M, Mornex J, Mal H, Treilhaud M, Dromer C, Quétant S, Leroy-Ladurie F, Guillemain R, Philit F, Dauriat G, Grenet D, Stern M: Lung transplantation for lymphangioleiomyomatosis: the French experience. Transplantation 2008, 86:5 I5-20.

\section{FlOOOPrime \\ RECOMMENDED}

120. Benden C, Rea F, Behr J, Corris PA, Reynaud-Gaubert M, Stern M, Speich R, Boehler A: Lung transplantation for lymphangioleiomyomatosis: the European experience. J Heart Lung Transplant 2009, 28: I-7.

121. Sato M, Okada Y, Oto T, Minami M, Shiraishi T, Nagayasu T, Yoshino I, Chida M, Okumura M, Date H, Miyoshi S, Kondo T: Registry of the Japanese Society of Lung and Heart-Lung Transplantation: official Japanese lung transplantation report, 2014. Gen Thorac Cardiovasc Surg 2014. 